\title{
Preliminary analysis of steelworks residues and their application in a sandy soil
}

\author{
Análise preliminar dos resíduos siderúrgicos e sua aplicação em um solo arenoso \\ Análisis preliminar de residuos de acero y su aplicación en suelo arenoso
}

Received: 03/31/2021 | Reviewed: 04/11/2021 | Accept: 04/19/2021 | Published: 05/03/2021

\author{
Mateus do Carmo Rocha \\ ORCID: https://orcid.org/0000-0002-6496-6133 \\ Universidade do Estado do Pará, Brazil \\ E-mail: mateusrochaea@gmail.com \\ Thais Binow Dias \\ ORCID: https://orcid.org/0000-0002-7215-2578 \\ Universidade do Estado do Pará, Brazil \\ E-mail: thaisbinowdias@gmail.com \\ Junimara Sarmento Chaves \\ ORCID: https://orcid.org/0000-0003-3815-6580 \\ Siderúrgica Norte Brasil, Brazil \\ E-mail: junimara.chaves@sinobras.com.br \\ Alisson Rangel Albuquerque \\ ORCID: https://orcid.org/0000-0002-4512-1071 \\ Universidade do Estado do Pará, Brazil \\ E-mail: alissonrangel@uepa.br \\ Milena Pupo Raimam \\ ORCID: https://orcid.org/0000-0001-9288-6926 \\ Universidade do Estado do Pará, Brazil \\ E-mail:milenaraimam@uepa.br
}

\begin{abstract}
The steel residues application (SR) in sandy soils, under a proper handling management, can result in a benefits range, among which, the soil acidity correction. This study investigated the gralunometric composition of three slags and one exhaustion powder from a steel mill, in the municipality of Marabá-PA, in addition to the ability of soil $\mathrm{pH}$ correction. To identify the granulometric fractions were used number $8,10,16$ and 18 mesh sieves. The $\mathrm{pH}$ correction experiment were made in factorial scheme, evaluated 3 doses of each RS (1.5 tha-1, $2.0 \mathrm{t}$ ha- 1 and $2.5 \mathrm{t}$ ha-1) in vases with Neosol, for 60 days. Residues from the steel refining (EAFS, LDS and EAFD) showed a particle size predominantly under $1.00 \mathrm{~mm}$, and promoted $\mathrm{pH}$ values above to 7.0. The blast furnace slag obtained domain of particle sizes $>2.00$ $\mathrm{mm}$, with $77 \%$ of the material retained in the sieves, and their soil disposition promoted similar results to dolomitic limestone, used traditionally to $\mathrm{pH}$ correction in acid soils, representing an alternative in soil preparation. Others residues also showed the soil $\mathrm{pH}$ correction capacity, although the used dosages proved to be above the ideal, with values above 7 and alkalinity tendency. The necessity of an investigation of EAFS, LDS and EAFD residues dosage are essential to $\mathrm{pH}$ soil correction, in order to condition the soil to $\mathrm{pH}$ ranges considered ideals (6-6.5).
\end{abstract}

Keywords: Environmental management; Granulometry; pH; Reactivity.

\section{Resumo}

A aplicação de resíduos siderúrgicos (RS) em solos arenosos, sob uma gestão de manejo adequada, pode resultar em uma gama de benefícios, dentre os quais, a correção da acidez do solo. Este estudo investigou a composição granulométrica de três escórias e um pó de exaustão gerados em uma usina siderúrgica no município de Marabá-PA, além da capacidade de correção do pH em solo. Foram utilizadas peneiras de malhas no 8, 10, 16 e 18 (ABNT) para determinar as frações granulométricas. O experimento de correção de $\mathrm{pH}$ realizado em esquema fatorial, avaliou 3 doses de cada RS (1,5 t.ha-1, 2,0 t.ha-1 e 2,5 t.ha-1) em vasos com neossolo, por 60 dias. Os resíduos provenientes do refino do aço (EAFS, LDS e EAFD) apresentaram granulometria predominante inferior a $1,00 \mathrm{~mm}$, e promoveram valores de $\mathrm{pH}$ superiores a 7,0. A escória de alto forno obteve dominio a granulometrías $>2,00 \mathrm{~mm}$, com $77 \%$ do material retido nas peneiras, e sua disposição no solo promoveu resultados similares ao calcáreo dolomítico tradicionalmente utilizado para a correção de $\mathrm{pH}$ em solos ácidos, podendo representar uma alternativa no preparo do solo. Os demais resíduos também apresentaram capacidade de correção do solo, embora as doses utilizadas demonstraram ser acima do ideal, com valores acima de $>7$ e tendência a alcalinidade. A necessidade de uma investigação da dosagem nos resíduos EAFS, LDS e EAFD são imprescindíveis a correção de pH do solo, no intuito de condicionar o solo a faixas considerados ideais do $\mathrm{pH}(6-6,5)$.

Palavras-chave: Gestão Ambiental; Granulometria; pH; Reatividade. 


\section{Resumen}

La aplicación de residuos de acero (RA) en suelos arenosos, bajo un manejo adecuado, puede resultar en una serie de beneficios, entre los cuales, la corrección de la acidez del suelo. Este estudio investigó la composición granulométrica de tres escorias y un polvo de escape generado en una planta siderúrgica del municipio de Marabá-PA, además de la capacidad de corregir el pH en el suelo. Se utilizaron tamices de malla número 8, 10, 16 y 18 (ABNT) para determinar las fracciones de tamaño de partícula. El experimento de corrección de $\mathrm{pH}$ realizado en un esquema factorial, evaluó 3 dosis de cada RS (1,5 t.ha-1, 2,0 t.ha-1 y 2.5 t.ha-1) en floreros con neossol, durante 60 días. Los residuos del refino de acero (EAFS, LDS y EAFD) presentaron un tamaño de partícula predominante por debajo de 1,00 mm y promovieron valores de $\mathrm{pH}$ superiores a 7,0. La escoria de alto horno tuvo un tamaño de dominio> 2,00 $\mathrm{mm}$, con $77 \%$ del material retenido en los tamices, y su disposición en el suelo promovió resultados similares a la caliza dolomítica tradicionalmente utilizada para la corrección de $\mathrm{pH}$ en suelos ácidos, lo que puede representar una alternativa en preparación del suelo. Los demás residuos también mostraron capacidad para corregir el suelo, aunque las dosis empleadas resultaron ser superiores al ideal, con valores superiores a $>7$ y tendencia a la alcalinidad. La necesidad de una investigación de la dosificación en residuos de EAFS, LDS y EAFD es fundamental para corregir el pH del suelo, con el fin de acondicionar el suelo a rangos considerados ideales para $\mathrm{pH}(6-6,5)$.

Palabras clave:Gestión ambiental; Granulometría; pH; Reactividad.

\section{Introduction}

Historically, the soil is considered one of the main bases of agricultural production (Jenny, 1980; Silva et al., 2018), among with the management techniques introduced by the man and the investment capital of agricultural sector (Reichardt \& Timm, 2016). Its formation is closely related to the combined number of physical, chemical and biological factors, followed by the climate actions that interact and tend towards equilibrium (Lal \& Stewart, 2019). Worldwide, its noticed a wide soils variety under distinct physical-chemical particularities (Brevik \& Hartemink, 2010), highlighted the fertility and their granulometries (Araújo et al., 2012).

In Brazil, sandy texture soils also have the denomination of light or dry soils (Schaetzl \& Thompson, 2015), with an $8 \%$ predominance in the Brazilian territory, with distribution in the Cerrado biome, specifically on the MAPITOBA region, which cover the states of Maranhão, Tocantins, Piauí and Bahia (Lumbreras et al., 2015; Bolfe et al., 2016), under dominance of Quartzarenic Neosols and small portions of Latosols and Argisols (Donagemma et al., 2016).

In general, Cerrado soils are highly weathered, of high depth and good drainage, but of precarious natural fertility (Fryrear, 1990; Lopes \& Guilherme, 2016; Centeno et al., 2017; Gomes et al, 2019). The sandy fraction can represent up to $70 \%$ of the composition and its granulometry variated between 0.05 and $2.00 \mathrm{~mm}$ (Santos et al., 2019), resulting in high permeability, an important property when observing the groundwater contamination risks (Benghalia et al., 2015).

In tropical and subtropical soils, due to high pluviometric precipitations and nutrients leaching, the cationic micronutrients being iron $(\mathrm{Fe})$, manganese $(\mathrm{Mn})$, zinc $(\mathrm{Zn})$, copper $(\mathrm{Cu})$, cobalt $(\mathrm{Co})$, together with aluminum $\left(\mathrm{Al}^{3+}\right)$ have larger concentrations compared to soluble cations of calcium $(\mathrm{Ca})$, magnesium $(\mathrm{Mg})$, nitrogen $(\mathrm{N})$, phosphorus $(\mathrm{P})$ and potassium (K) (Fageria \& Stone, 2008), which may lead to agricultural production problems, due to the potential toxicity and pH variations (Serafim et al., 2019).

When the basic cations release rate is exceeded by their removal, the soil $\mathrm{pH}$ decreases, resulting in acid soils to the environment (Chenu et al., 2018). Cerrado soils $\mathrm{pH}$ has values in the 4.3 to 6.2 range, resulting in classes considered as medium ( $\mathrm{pH}>5.0-5.9)$ and high acidity ( $\mathrm{pH}<5.0)$ (Carvalho et al., 2009; Hunke et el., 2014; Lopes \& Guilherme, 2016; Rodrigues \& Silva, 2020). In Brazil, around $70 \%$ of the territory is composed by lands in excessive or moderate acidity (Sumner \& Noble, 2003; Xu et al., 2020).

Sandy soils at $\mathrm{pH} \leq 5.5$ have the peculiarities of being toxics and inappropriate for agriculture when the potential acidity cause by the high $\mathrm{Al}^{3+}$ saturation is related to low capacity of cations exchange (CTC) and Ca-Mg-K leaching (Lopes \& Cox, 1977; Hunke et al., 2014; Reichert et al., 2016). The increase of $\mathrm{Al}^{3+}$ rates in acid soils is a reflection of the hydrogen 
performance $\left(\mathrm{H}^{+}\right)$over the low activity minerals, as kaolinite for example $\left(\mathrm{Al}_{4}\left(\mathrm{Si}_{4} \mathrm{O}_{10}\right)(\mathrm{OH})_{8}\right)$, releasing the $\mathrm{Al}^{3+}$ ions that are retained on the negative charges of clay particles, tending to balance (Yong, Nakano, \& Pusch, 2012).

Acid soils, with high concentrations of $\mathrm{Al}^{3+}$, negatively influences the soil microbiota (Echart \& Cavalli-Molina, 2001; Ranger, 2018). Bacterial diversity index decrease in sandy soils occurs in $\mathrm{pH}<6$ values (Fernandes et al., 2012). The $\mathrm{Al}^{3+}$ accumulation, when damage the roots membrane cells, inhibits the plants root growth, harming the interaction with soil nutrients and limiting the plant metabolism (Ozores-Hampton, Stansly, \& Salame, 2011).

Considering the mentioned aspects, among others, these soils show low relevance for agriculture, since the low nutritional rate and the susceptibility to erosion from wind and rain, result in difficulties in soil preparation and increases the spends with correctives and fertilizers (Fryrear, 1990; Colazo \& Buschiazzo, 2015; Ferreira et al, 2017; Verruijt, 2018).

The $\mathrm{pH}$ correction and the increment of macro and micronutrients to the soil, are common practices and indispensable in the current agriculture (Crespo-Mendes et al., 2019). Wood ashes, marl, hydrated lime $\left(\mathrm{Ca}(\mathrm{OH})_{2}\right)$ and the calcitic $\left(\mathrm{CaCO}_{3}\right)$, dolomitic $\left(\mathrm{CaMg}\left(\mathrm{CO}_{3}\right)_{2}\right)$ and calcined $(\mathrm{CaO})$ limestones are considered the most frequent materials used for this purpose (Brady \& Wile, 2013). In sandy soils, the liming associated with the use of Nitrogen-Phosphorus-Potassium (NPK) fertilizers is considered a managerial practice of great agricultural effectiveness, having as benefits the increase of water retention capacity (Esper Neto et al., 2019), the $\mathrm{H}^{+}$ions neutralization, reduction of $\mathrm{Al}^{3+}$ and $\mathrm{Fe}^{2+}$ and availability of $\mathrm{P}, \mathrm{K}$ and $\mathrm{S}$ to the soil (Centeno et al., 2017; Li et al., 2019).

Steel slag and dust have been used in the soil as $\mathrm{pH}$ correctors and fertilizers in several countries such as China, Japan, South Korea and the United States (Sobral et al., 2011; Deus \& Büll, 2013; Seh-Bardan et al., 2013; Wally et al., 2015; Guo, Bao \& Wang, 2018; Oza et al., 2018; Brasil \& Nascimento, 2019; Das et al., 2019; Deus et al., 2020). Its use is linked to the chemical composition, formed predominantly by oxides of silicon, calciu m, aluminum and phosphorus (Kimio, 2015; Piatak, Parsons \& Seal, 2015).

The steel industry, currently, is characterized as an activity which requires a large amount of matter and energy for the production of steel in different specifications, which has been accompanied by a diversified origin of solid residues, liquids or gaseous effluents (Liubartas et al., 2015; Gomes et al., 2016; Pulin et al., 2019). In 2019, Brazilian steel producing companies generated a total of 18 million tons of residues, distributed in Mud (4\%), fine aggregate (6\%) and Blast-furnace Slag (39\%) and steelwork (26\%) (IAB, 2020).

The application of these steel residues in sandy soils still needs researches (Ghosh \& Ghosh, 2020), which can elucidate the behavior of the elements in the soil matrix as well as their percolation, since that, they can cause impacts in the ecosystem trophic chains, due to bioaccumulative heavy metals presence and soil high salinity presence (Chand, Paul, \& Kumar, 2015; Mena et al., 2020).

In this sense, the hypothesis of the study were: (1) the steel residues has the capacity of $\mathrm{pH}$ correction of an acid soil; (2) residues with higher reactivities in the soil have a high charge of materials in its composition. Therefore, the objective of this article was to investigate preliminarily the physical-chemical properties of steel residues and their capacity of $\mathrm{pH}$ correction, when applied on a sandy soil.

\section{Methodology}

\subsection{Research characterization}

The method applied to the study was hypothetical-deductive, with the presentation of the problem followed by hypotheses formulation for the searching of possible results, by observing and experimenting about the steelworks residues applied in a sandy soil (Marconi \& Lakatos, 2017). The research obtained quantitative coverage under applied nature, with 
explanatory and experimental characteristics, which aim to provide greater familiarity of aspects with the object of study, as described in the four steps of figure 1 (Gil, 2018).

Figure 1. Research design.

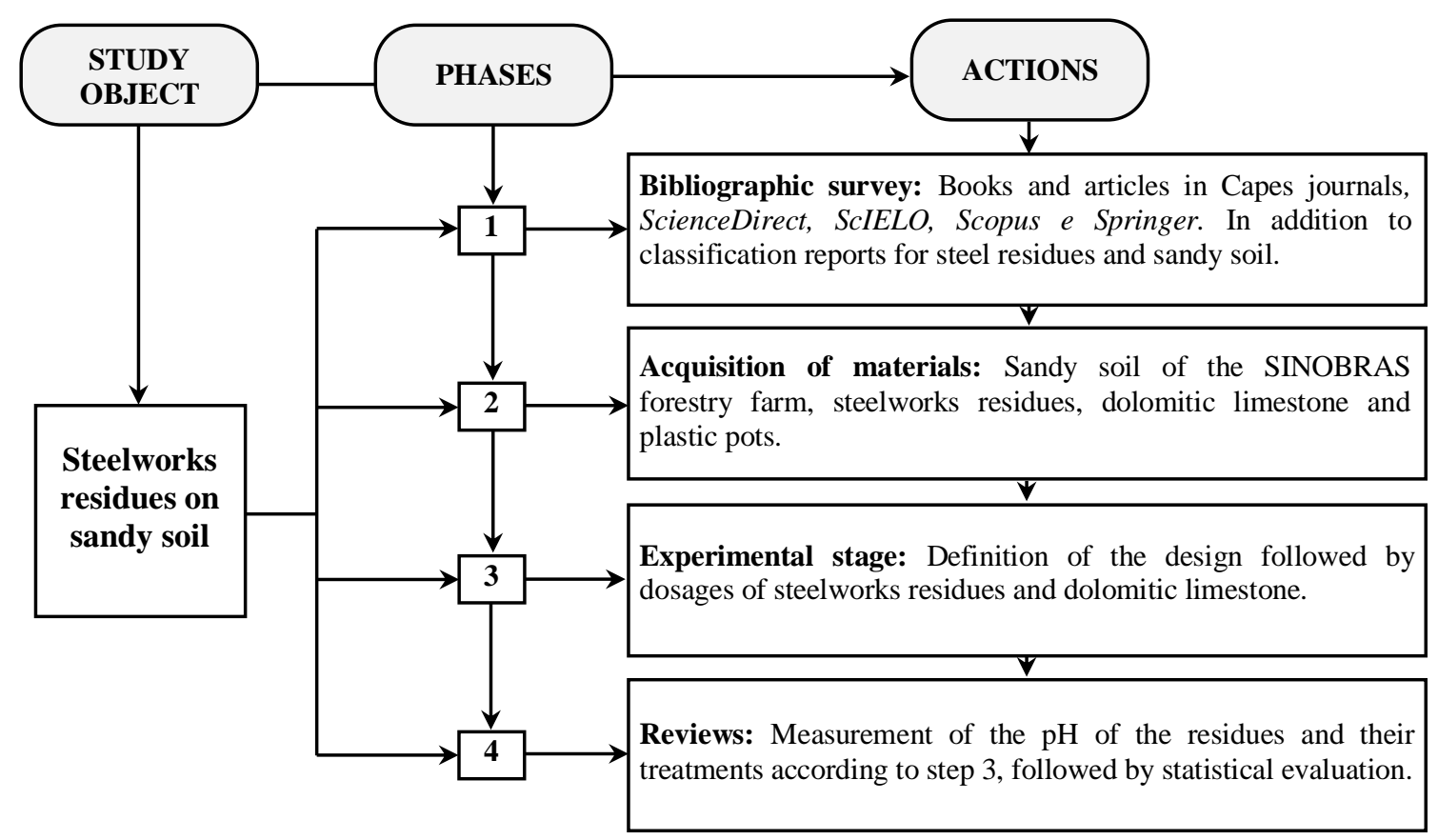

Source: Authors (2020).

\subsection{Study Area}

The experiment was conducted between the months of 2019 March and April, on the Laboratory of Bioproducts and Biomass Energy (LABBIM), with localization in Pará State University, in the municipality of Marabá - Pará.

\subsection{Experimental Design}

The experimental units were constituted by plastic vases with $500 \mathrm{~mL}$ capacity, composed by a sandy soil of the Dystrophic Quartzarenic Neosol, according to Embrapa classification (2018), collected in the 0-20 cm depth. Physicalchemical properties are presented in the table 1.

Table 1. Physical-chemical properties of the soil used in the experiment.

\begin{tabular}{|c|c|c|c|c|c|c|c|c|c|c|c|c|}
\hline \multirow{2}{*}{ pH } & \multirow{2}{*}{$\mathrm{Ca}^{2+}$} & \multirow{2}{*}{$\mathrm{Mg}^{2+}$} & \multirow{2}{*}{$\mathbf{H}+\mathbf{A l}$} & \multirow{2}{*}{$\mathbf{K}^{+}$} & \multirow{2}{*}{$\mathbf{N a}^{+}$} & \multirow{2}{*}{$\mathbf{A l}^{3+}$} & \multicolumn{2}{|c|}{ CTC } & \multirow{2}{*}{$\mathbf{V}$} & \multicolumn{3}{|c|}{ Granulometry } \\
\hline & & & & & & & ef. & $\mathrm{T}$ & & Sand & Silt & Clay \\
\hline & & & & & & & & ------ & $(\%)$ & ------ & $(6 \mathrm{l}$ & \\
\hline 4.50 & 0.50 & 0.20 & 2.30 & 0.02 & 0.01 & 1.0 & 1.72 & 3.02 & 24 & 880 & 40 & 80 \\
\hline
\end{tabular}

Source: Sinobras Florestal (2019).

The residues evaluated are from an integrated steel mill, composed by all steps in the steel production (figure 2). From the steel reduction process, the Blast furnace slag (BFS) was used, while from the refining was the electric arc furnace slag (EAFS), ladle furnace slag (LDS) and electric arc furnace dust (EAFD). 
Figure 2. Steel production process in integrated and semi-integrated mill.

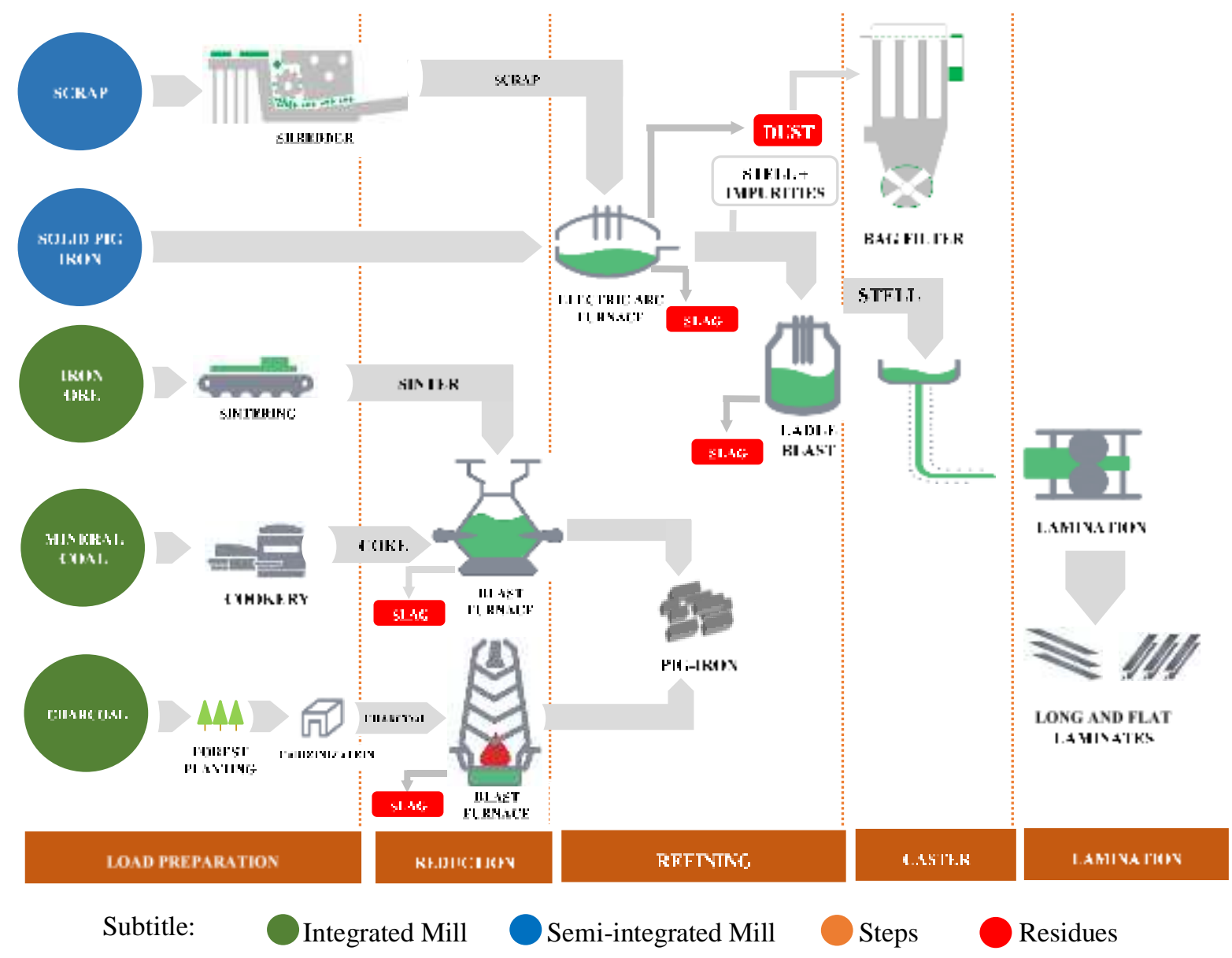

Source: Adapted from IAB (2014).

Materials, highlighted in the productive process flowchart (figure 2), were LABBIM provided by Siderúrgica Norte Brasil (SINOBRAS) and chemically characterized according to table 2.

Table 2. Chemical composition of steelworks residues.

\begin{tabular}{|c|c|c|c|c|c|c|c|c|c|}
\hline RESIDUES & $\mathbf{N a}$ & $\mathbf{B a}$ & $\mathrm{NO}^{3-}$ & $\mathrm{SO}_{4}^{-2}$ & $\mathbf{C l}$ & $\mathbf{F}$ & Al & $\mathrm{Cr}$ & $\mathbf{P b}$ \\
\hline & \multicolumn{9}{|c|}{ - } \\
\hline BFS & 2.5 & 0.03 & 0.03 & 4 & 2 & 0.14 & 0.09 & $*$ & $*$ \\
\hline EAFS & 3.1 & 0.34 & 0.06 & 4 & 8 & 0.17 & 2.21 & $*$ & $*$ \\
\hline LDS & 22.1 & 0.59 & 0.08 & 10 & 74 & 0.56 & $*$ & 1.44 & 0.15 \\
\hline EAFD & 423.8 & 0.02 & 2.45 & 2625 & 6461 & 0.82 & $*$ & 4.99 & 11.45 \\
\hline
\end{tabular}

Subtitle: *not detected. BFS = Blast furnace slag; EAFS = Electric arc furnace slag; LDS = Ladle furnace slag; EAFD = Electric arc furnace dust. Source: SINOBRAS (2019).

At the time of collection, the residues were packed in inert polymer bags, according to NBR 10007 (ABNT, 2004b), and submitted to $\mathrm{pH}$ analysis, according to NBR 10006 (ABNT, 2004a), on the proportion of $250 \mathrm{~g}$ of residue in $1000 \mathrm{ml}$ of distilled water resting for 7 days prior to reading, in triplicate.

To the residues granulometric fractions determination (figure 3), their were dry previously at $105{ }^{\circ} \mathrm{C}$ in SOLAB SL102 circulation and air renovation oven for $24 \mathrm{~h}$, followed by sieving electromagnetic agitator of sieves mod. ALS-PA via, 
using the meshes number 8, 10, 16 and 18 according to ABNT, which matches respectively the openings of 2.36; 2.00; 1.18; $1.00 \mathrm{~mm}$ (Brasil \& Nascimento, 2019).

Figure 3. Steelworks residues aspect after sieving.
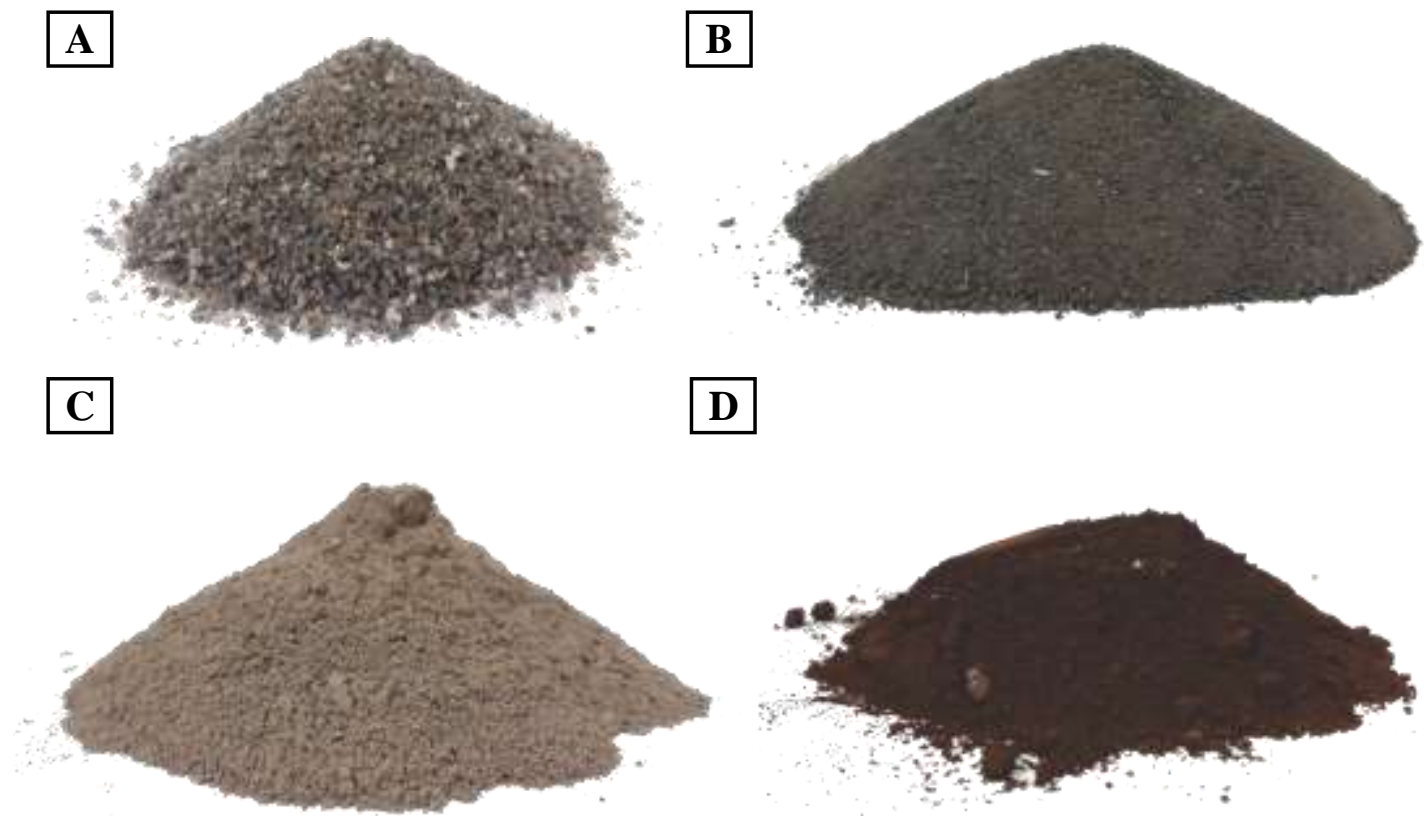

Subtitle: A) Blast furnace slag (BFS); B) Electric arc furnace slag (EAFS); C) Ladle furnace slag (LDS); D) Electric arc furnace dust (EAFD). Source: Authors (2020).

After the residues granulometry adjustments (figure 3), the experimental design was completely randomized, in $4 \times 3 \times 3+2$ fatorial scheme, with 4 steelwork residues, 3 dosages $\left(1,5 \mathrm{t} \mathrm{ha}^{-1}, 2,0 \mathrm{t} \mathrm{ha}^{-1}\right.$ and 2,5 $\mathrm{t} \mathrm{ha}^{-1}$, corresponding to 30 , 40 and $50 \mathrm{~g}$ per pot) and 3 repetitions, adding to 2 control treatments: dolomitic limestone $-\mathrm{DL}$ at $2.5 \mathrm{t}$ ha- $1(\mathrm{CaCO} 3+\mathrm{MgCO} 3$ in values above $25 \% \mathrm{CaO}$ and $13 \%$ of $\mathrm{MgO}$ ) and witness $(\mathrm{T})$ only the soil substrate, totaling 42 experimental units. The experiment was conducted, in the laboratory, for 60 days in environmental temperature and daily manual irrigation with distilled water.

At the end of the period, the $\mathrm{pH}$ value of the treatments were analyzed by the use of a LUCA-210 benchtop digital $\mathrm{pH}$ meter according to Teixeira et al. (2017), on the $100 \mathrm{~g}$ of soil to $250 \mathrm{ml}$ of distilled water proportion, with a $1 \mathrm{~h}$ rest before the measurement.

\subsection{Statistical Analysis}

The data of granulometric fractions and $\mathrm{pH}$ values were sequentially submitted to descriptive statistic, Shapiro-Wilk normality test $(\mathrm{p}>0,05)$, variance analysis and posteriorly the Tukey test at $5 \%$ of significance $(\mathrm{p}<0,05)$, using the IBM SPSS software, version 26 (IBM corp., 2019).

\section{Results and Discussion}

The table 3, presents the distribution of each steel residue by obtained fraction, where the blast furnace slag (BFS) showed $77 \%$ (384.84 g) of the material with granulometry greater than 2,0mm. 
Table 3. Granulometric distribution of the steelworks residues.

\begin{tabular}{|c|c|c|c|c|}
\hline Meshes & BFS & EAFS & LDS & EAFD \\
\hline ---- $(\mathrm{mm})$---- & \multicolumn{4}{|c|}{ 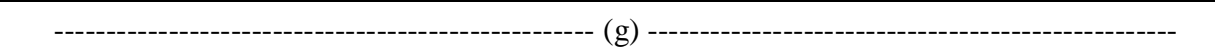 } \\
\hline$>2.36$ & $12.01 \pm 3.20 \mathbf{D a}$ & $1.36 \pm 0.35 \mathbf{D b}$ & $* *$ & $* *$ \\
\hline $2.36-2.00$ & $384.84 \pm 4.12$ Aa & $5.73 \pm 1.28 \mathrm{Db}$ & $* *$ & $* *$ \\
\hline $2.00-1.18$ & $47.44 \pm 1.66 \mathbf{B b}$ & $40.21 \pm 3.97 \mathbf{C b}$ & $64.58 \pm 0.11 \mathbf{C a}$ & $* *$ \\
\hline $1.18-1.00$ & $30.74 \pm 1.58 \mathbf{C c}$ & $141.22 \pm 3.22 \mathbf{B b}$ & $192.18 \pm 3.20 \mathbf{B a}$ & $0.27 \pm 0.04 \mathbf{B d}$ \\
\hline$<1.00$ & $25.61 \pm 1.44 \mathbf{C d}$ & $311.88 \pm 2.17 \mathbf{A b}$ & $243.67 \pm 1.70 \mathrm{Ac}$ & $499.33 \pm 0.14 \mathbf{A a}$ \\
\hline$\rho$-valor & $<0.001$ & $<0.001$ & $<0.001$ & $<0.001$ \\
\hline
\end{tabular}

Subtitle: **not detected Averages followed by the same capital letters in the column and small letters in the same line do not differ from each other by the Tukey test at 5\% of probability. BFS = Blast furnace slag; EAFS = Electric arc furnace slag; LDS $=$ Ladle furnace slag; EAFD = Electric arc furnace dust. Source: Authors (2020).

The other residues, as detailed in table 3, exposed mainly granulometries lower than 1.00mm, being EAFD with 99\% (499.33g), EAFS in 62\% (311.88g) and LDS 49\% (243.67g) of the material in $500 \mathrm{~g}$ corresponding to this fraction. The LDS and EAFD residues obtained granulometry from $<2.00 \mathrm{~mm}$ and $<1.18 \mathrm{~mm}$, being detectable from these meshes, respectively. Furthermore, considering the intervals 2.00 - 1.18 (table 3), the BFS(47.44 g) and EAFS (40.21 g) slag data were the only which do not differ statistically.

The steelworks residues granulometric determination in table 3, met the NBR 10006 normative (ABNT, 2004a), which advocates values $<9.5 \mathrm{~mm}$, therefore, it was not necessary to reduce the particle size of the materials, followed by them for $\mathrm{pH}$ analysis (figure 4).

Figure 4. Comparison of the steelworks residues $\mathrm{pH}$ values.

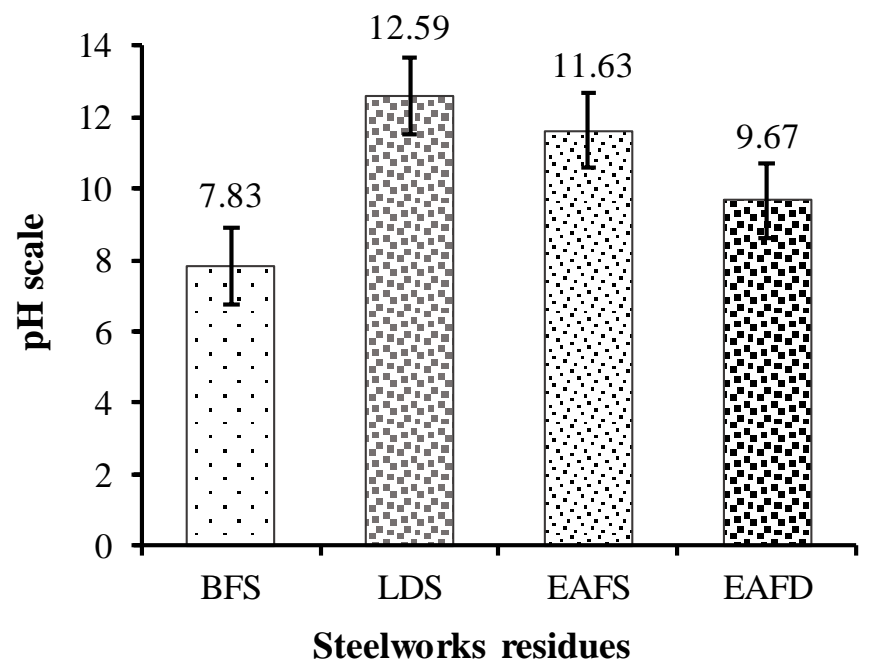

Subtitle: BFS = Blast furnace slag; EAFS = Electric arc furnace slag; LDS = Ladle furnace slag; EAFD = Electric arc furnace dust. Source: Authors (2020).

In figure 4, the $\mathrm{pH}$ values demonstrated high alkalinity of the different residues with LDS> EAFS> EAFD> BFS, and values between 7.83 for BFS and 12.59 at LDS. In addition, blast furnace slag (BFS) and electric arc furnace slag (EAFS) were the only residues to show $\mathrm{pH}$ values <10.Often, the physical-chemical composition of the steelworks residues is often usually quite heterogeneous, with the production model and the raw material used being the main factors of the alternation of values (Özbay, Erdemir, \& Durmuş, 2016; Buzin, Heck \& Vilela, 2017; Jiang, et al., 2018; Ghosh \& Ghosh, 2020). The scrap used in the steelworks (reduction) has been the main input to electric furnaces, which demands higher concentrations of fluxes $(\mathrm{CaO}$ 
and $\mathrm{MgO}$ ) in the process of separating impurities from the metallic alloy (Stathopoulos et al., 2013; Sadek, 2014 ; Alharahsheh et al., 2019).

Teo et al (2020) highlights that the residues from steel refining sector (EAFS, LDS e EAFD) have more impurities when compared to those from the blast furnaces that produce pig iron (BFS), which reflects, particularly, in the formation of more amorphous and easily disintegrating material aggregates, and contributes to a smaller effectiveness of its granulometrics decrease in the ring mill. Residue finest fractions, results in materials with higher $\mathrm{pH}$ values, which in contact with the soil matrix, release hydroxyls in solution, in a way that alters the hydrogenionic potential (Gomes et al., 2016; Brasil \& Nascimento, 2019), justifications that correspond to the presented values of granulometry $<1.18 \mathrm{~mm}$ (table 3$)$ and $\mathrm{pH}>7$ (figure 4).

All the steelworks residues promoted soil $\mathrm{pH}$ elevations shown in figure 5 , differing of the witness (T) and DL, in order LDS $>$ EAFS $\geq$ EAFD $>$ BFS $\geq$ DL $>$ T (figure 5).

Figure 5. Values of $\mathrm{pH}$ in soil treated with different doses of steelworks residues.

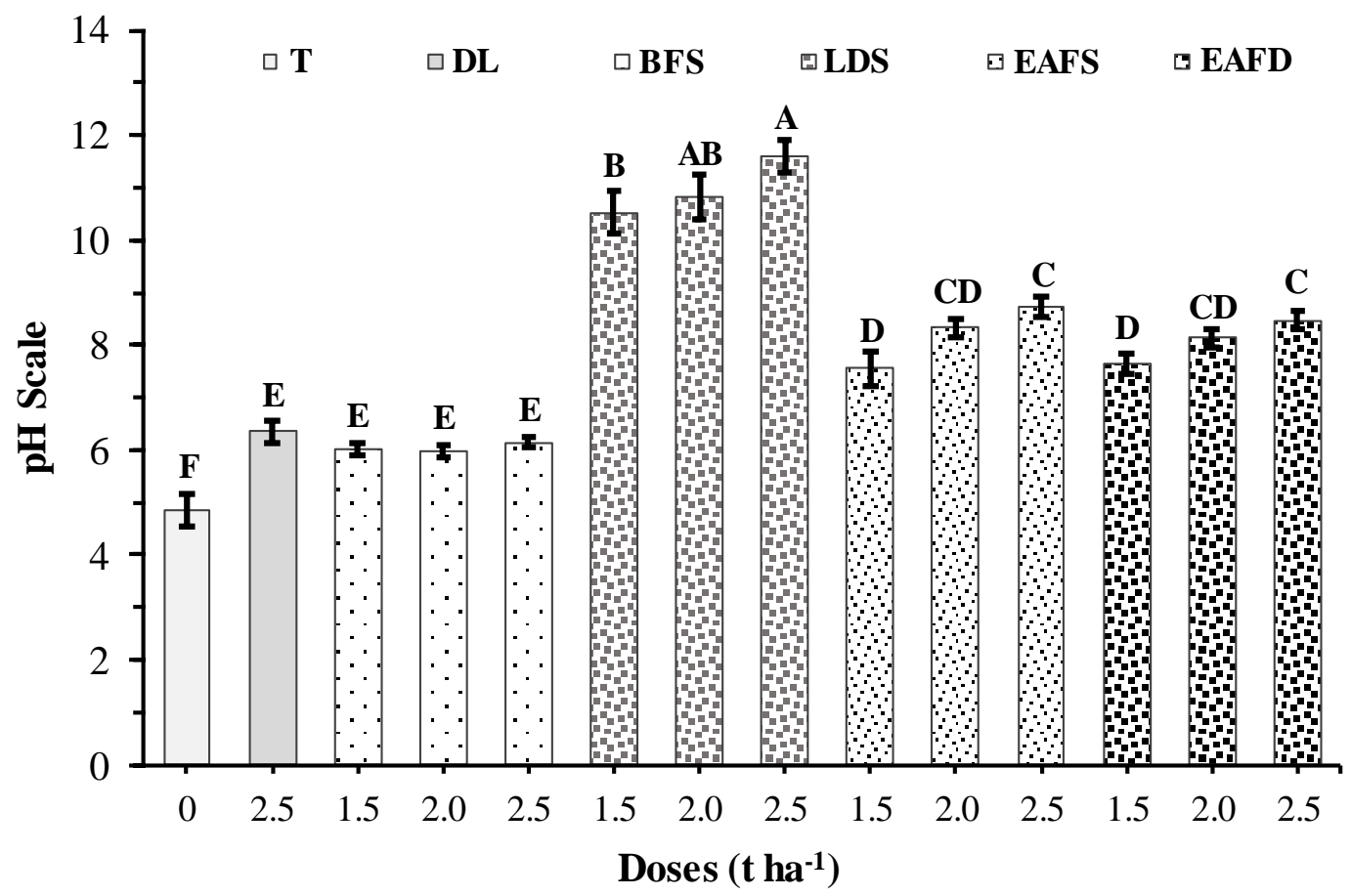

Subtitle: Averages followed by the same capitol letter, do not differ from each other by the Tukey test at $5 \%$ of probability. $\mathrm{BFS}=$ Blast furnace slag; EAFS = Electric arc furnace slag; LDS = Ladle furnace slag; EAFD = Electric arc furnace dust. Source: Authors (2020).

The LDS, elevated in $144 \%$ the soil pH (figure 5), considering the three tested doses, varying from 10.52 to 11.60. Added to that, doses with EAFS and EAFD raised the $\mathrm{pH}$ by $(\bar{x}=8,20)$ e $79 \%(\bar{x}=8,08)$,respectively, differing from the other treatments, but not from each other. The BFS promoted an increase of $34 \%$ in the pH, matching up with the DL treatment only, regardless of the considered dose, raising the $\mathrm{pH}$ from 4.5 to 5.97 to 6.35 . Moreover, the intermediate dose $\left(2.0 \mathrm{t}\right.$ ha $\left.{ }^{-1}\right)$ of the LDS, BFS and EAFD residues in figure 5, do not behave in a similar way to the 1.5 and $2.5 \mathrm{t} \mathrm{ha}^{-1}$ dose, with no statistical difference.

The steelworks residues presented granulometrics $<2.00 \mathrm{~mm}$, with this they have particularities in aggregates of finer fractions, suitable for soil correction (Brady \& Weil, 2013; Esper Neto et al., 2019; Lozano-lunar et al, 2019), as they have 
effective solubilization and rapid stabilization of materials to the soil when compared to conventionally used limestones, resulting in faster soil correction (Deus \& Büll, 2013; Sol-Sánchez et al, 2016). Nascimento, Brasil and Silva (2019) investigating the corrective effect of different doses and granulometries of slag in dystrophic yellow latosol verified that fractions lower than $2.00 \mathrm{~mm}$ promoted improvements in the soil chemical attributes compared to the conventional corrective, by raising the $\mathrm{pH}$ and provide nutrients.

In particular, BFS in the soil with a tendency to a light acidity $(\mathrm{pH}>6.0-6.9)$ shown in figure 5 , have been observed in several studies, bringing satisfactory results in the decrease of exchangeable aluminum and increase of $\mathrm{Ca}^{2+}, \mathrm{K}^{+}$and $\mathrm{Mg}^{2+}$ availability under different brazilian soils, highlighting the Ortics Quartzarenic Neosols (Nolla et al., 2013; Pereira et al., 2004), Haplic Cambisols (Nascimento et al., 2015), and Dystrophic Red-Yellow Latosols (Brasil \& Nascimento, 2019; Corrêa et al., 2009; Deus \& Büll, 2013; Nogueira et al., 2012). Pereira et al (2010), do not obtained satisfactory results in the soil correction and release of $\mathrm{Ca}^{2+}$ and $\mathrm{Mg}^{2+}$ by blast furnace slags with $>2.00 \mathrm{~mm}$ texture.

Das et al (2019), demonstrated that blast furnace slag rich with the $\mathrm{SiO}_{3}{ }^{2-}$ silicon form and soluble cations $(\mathrm{Ca}, \mathrm{Mg}, \mathrm{K}$ and $\mathrm{Na}$ ), in contact with acid lands tend to decrease the $\mathrm{H}^{+}$and $\mathrm{Al}^{3+}$ ions, due to the material hydrolysis and the increase of essential nutrients for the soil. Benefits in rice productivity in a controlled environment, after the application of $2 \mathrm{mg}^{-1}$ of BFS, are reported by Gwon et al (2018). The authors related the gains with soil acidity correction, to the microbial increase and nutrients mobilization.

Recommendations for the use of agricultural correctives are calculated based on the potentiality for total neutralization and reactivity of these compounds in the soil (Besen et al., 2021; MAPA, 2017). Studies aimed to define doses for steel residues use as correctives simulating the possible benefits, limitations to plant growth and its productivity, are essential since the reactive behavior of these in the soil has been shown to be quite variable (Deus \& Büll, 2013; Deus et al., 2020).

The alkaline peculiarity of steel residues (figure 4), with use above what is recommended, can result in an increase in pH in the soil, and may even cause environmental damage (Scattolin et al., 2021), as was verified in patios with slag deposits (Gomes et al., 2016). Studies with application of electric arc furnace slag influenced in the Canavalia ensiformis DC. (Feijãode-porco) growth, with low biomass production in alkaline soils (pH > 7) (Oliveira \& Souza, 2020). It is noteworthy that EAFS residue of the authors had similar $\mathrm{pH}$ values in the soil (figure 5) with dosages greater than $30 \mathrm{mg} \mathrm{dm}^{-3}(\mathrm{pH}=7.00-$ 8.73), with the residue from the same origin of the productive process.

An analysis performed by Seh-Bardan et al (2013) demonstrated the equal doses or higher than 2\% of EAFD raised the soil $\mathrm{pH}$ to level above of the intended, inhibiting the sorghum growth (Sorghum bicolor L.), with decrease of biomass production, increasing the salinity and critical loads of potentially toxics elements $(\mathrm{Fe}, \mathrm{Mn}, \mathrm{Zn}, \mathrm{Cu}, \mathrm{Cd}$ and $\mathrm{Pb}$ ) in the soil. These results matches with data obtained in the present study (figure 5), which the EAFD doses equal to or greater than $1.5 \mathrm{t}$ $\mathrm{ha}^{-1}$ resulted in high $\mathrm{pH}$ values (higher than 7.64).

Rocha et al (2019) in a study about EAFD doses in sandy soil, observed that leaching rate (TL) of underground water is inversely proportional to the residue concentration and that the micrometric granulometry facilitated the material reactivity, with the increase of soil alkalinity $(\mathrm{pH}>7.5)$. To know the infiltration rate and the porosity changes in steel treated soils is important, since that drainage changes, aeration, infiltration profile can influence the mobility and elements availability (Silva et al., 2020).

Balancing density with porosity in sandy soils promotes improvements in water retention and minimizes the nutrients loss by leaching (Nunes et al., 2020). The conventional agricultural correctives presented textures between 0.15 and $0.30 \mathrm{~mm}$, with predominance lower than $2.0 \mathrm{~mm}$ (Brady \& Weil, 2013). This granulometric characteristic answers for a large part of the 
compound corrective action, as it determines the contact surface (specific surface) between the corrective substance and the soil fractions, which in turn interferes with the dissolution and neutralization power (Verruijt, 2018; Wang et al., 2020).

The excessive use of agricultural correctives in light soils, influences in the total filling of porous spaces, resulting in the decrease of water infiltration rate, reduction of gas exchanges $\left(\mathrm{O}_{2}\right.$ e $\left.\mathrm{CO}_{2}\right)$ and erosion susceptibility (Yong, Nakano, \& Pusch, 2012; Crespo-Mendes et al., 2019). Physical degradation of these soils is resulting from the shear tension and consequently the increase of soil surface flow (Bayat \& Ghalandarzadeh, 2018).

Cunha et al (2014) highlight that salinity is intrinsically related to the increase in soil pH and CTC, which favors the retention of potentially toxic elements in the surface layers (Ning et al., 2016). This behavior also points out to the care with the use of steel residues in agriculture, due to the presence of toxic metals that can inhibit microbial activity and root growth (Wan et al, 2019; Mena et al., 2020.).

Acosta et al (2011) points out that soil with $\mathrm{pH}$ greater than 7, are susceptibles to low mobility and bioavailability of the metalic ions $\mathrm{Cu}^{2+}, \mathrm{Zn}^{2+}, \mathrm{Ni}^{2+}, \mathrm{Mn}^{2+}, \mathrm{Fe}^{2+}, \mathrm{Cr}^{2+}, \mathrm{Co}^{2+}, \mathrm{Pb}^{2+}$ and $\mathrm{Cd}^{2+}$, making difficult the plant absorption. In this aspect, the behavior observed by BFS was appropriate to the soil correction of agriculturable areas. On the other hand, the proportions of EAFS, LDS and EAFD showed elevated, requiring tests with doses lower than 1.5 t.ha ${ }^{-1}$.

\section{Conclusion}

The steelworks residues presented granulometry characteristics and $\mathrm{pH}$ correction capacity compatibles to the conventional agricultural correctives. Among the analyzed residues, the blast furnace slag promoted equal results to dolomitic limestone, which may represent a lower cost alternative in soil preparation.

New tests evaluating lower dosages of EAFD, EAFS and LDS residues, or even a possible chemical adaptation prior to its use, are necessary to investigate the correction effects and soil protection, as the heavy metal accumulation, salinity increase and biodiversity maintenance.

\section{Acknowledgments}

To Empresa Siderúrgica Norte Brasil S.A (SINOBRAS) for the supply of steel residues and soil used in the experiment.

\section{References}

Acosta, J. A., Jansen, B., Kalbitz, K., Faz, A., \& Martínez-Martínez, S. (2011). Salinity increases mobility of heavy metals in soils. Chemosphere, 85 (8), 1318-1324. https://doi.org/10.1016/j.chemosphere.2011.07.046

Al-Harahsheh, M., Al-Nu'aiarat, J., Al-Otoom, A., Al-hammouri, A., Al-jabali, H., Al-zoubi, M., \& Al'asal, S. A. (2019). Treatments of electric arc furnace dust and halogenated plastic wastes: A review. Journal of Environmental Chemical Engineering, 7 (1), 102856. https://doi.org/10.1016/j.jece.2018.102856

Araújo, E. A., Ker, J. C., Neves, J. C. L., \& Lani, J. L. (2012). Qualidade do solo: conceitos, indicadores e avaliação. Revista Brasileira de Tecnologia Aplicada nas Ciências Agrárias, 5 (1),187-206. https://doi.org/10.5777/paet.v5i1.1658

Associação Brasileira de Normas Técnicas [ABNT] (2004). ABNT NBR 10.006: Procedimento para obtenção de extrato solubilizado de resíduos sólidos. Rio de Janeiro: ABNT.

Associação Brasileira de Normas Técnicas [ABNT] (2004). ABNT NBR 10.007: Amostragem de resíduos sólidos. Rio de Janeiro: ABNT.

Bayat, M., \& Ghalandarzadeh, A. (2018). Stiffness Degradation and Damping Ratio of Sand-Gravel Mixtures Under Saturated State. International Journal of Civil Engineering, 16, 1261-1277. https: //doi.org/10.1007/s40999-017-0274-8.

Benghalia, Y., Bouafia, A., Canou, J., \& Dupla, J. C. (2015). Liquefaction susceptibility study of sandy soils: effect of low plastic fines. Arabian Journal of Geosciences, 8 (2), 605-618. https://doi.org/10.1007/s12517-013-1255-0 
Besen, M. R., Esper Neto, M., Cassim, B. M. A. R., Minato, E. A., Inoue, T. T., \& Batista, M. A. (2021). Potential Waste Application of Several Industries Segments in Brazilian Agriculture: Effects on Physical and Chemical Soil Properties. Communications in Soil Science and Plant Analysis, 1-24. https://doi.org/10.1080/00103624.2021.1892732

Bolfe, É. L., Victória, D. C., Contini, E., Bayma-Silva, G., Spinelli-Araujo, L., \& Gomes, D. (2016). Matopiba em Crescimento agrícola: Aspectos territoriais e socioeconômicos. Revista de política agrícola, 1 (4), 38-62.

Brady, N. C. \& Weil, R. R. (2013). Elementos da natureza e propriedades dos solos (3a ed.). Porto Alegre: Bookman.

Brasil, E. C. \& Nascimento, E. V. S. (2019). Aproveitamento agronômico de escória de siderurgia de alto-forno na correção da acidez do solo.Belém: Embrapa Amazônia Oriental.

Brevik, E. C., \& Hartemink, A. E. (2010). Early soil knowledge and the birth and development of soil science. Catena, 83 (1) 23-33. https://doi.org/10.1016/j.catena.2010.06.011

Buzin, P. J. W. K., Heck, N. C., \& Vilela, A. C. F. (2017). EAF dust: An overview on the influences of physical, chemical and mineral features in its recycling and waste incorporation routes. Journal of Materials Research and Technology, 6 (2), 194-202. https://doi.org/10.1016/j.jmrt.2016.10.002

Carvalho, J. L. N., Cerri, C. E. P., Feigl, J., Píccolo, M. C., Godinho, V. P., Herpin, U., \& Cerri, C. C. (2009). Conversion of Cerrado into agricultural land in the south-western Amazon: Carbon stocks and soil fertility. Scientia Agricola, 66 (2), 233-241. https://doi.org/10.1590/S0103-90162009000200013

Centeno, L. N., Guevara, M. D. F., Cecconello, S. T., Sousa, R. O.D., \& Timm, L. C. (2017). Textura do solo: Conceitos e aplicações em solos arenosos. Revista Brasileira de Engenharia e Sustentabilidade, 4 (1) 31-37.

Chand, S., Paul, B., \& Kumar, M. (2015) An Overview of Use of Linz-Donawitz (LD) Steel Slag in Agriculture. Current World Environment, 10 (3), $975-984$. https://doi.org/10.12944/CWE.10.3.29

Chenu, C., Roger-Estrade, J., Gascuel, C., \& Walter, C. (2018). Soils, a Factor in Plant Production: Agroecosystem. In: Berthelin, J., Valentin, C., \& Munch, J. C. Soils as a Key Component of the Critical Zone 1: Functions and Services. (Vol. 1, Chap. 6, pp. 147-162). London: ISTE Ltd. https://doi.org/10.1002/9781119438069.ch6

Colazo, J. C., \& Buschiazzo, D. (2015). The Impact of Agriculture on Soil Texture Due to Wind Erosion. Land Degradation and Development, 26 (1), 62-70. https://doi.org/10.1002/ldr.2297

Corrêa, J. C., Bull, L. T., Crusciol, C. A. C., \& Moraes, M. H. (2009). Alteração de atributos físicos em Latossolo com aplicação superficial de escória de aciaria, lama cal, lodos de esgoto e calcário. Revista Brasileira de Ciência do Solo, 33 (2), 263-272. http://dx.doi.org/10.1590/S0100-06832009000200004

Crespo-Mendes, N., Laurent, A., Bruun, H. H., \& Hauschild, M. Z. (2019). Relationships between plant species richness and soil pH at the level of biome and ecoregion in Brazil. Ecological Indicators, 98, 266-275. https://doi.org/10.1016/j.ecolind.2018.11.004

Cunha, C. S. M. Hernandez, F. F. F., Silva, F. N., Escobar, M. E. O., Magalhães, D. R., \& Anjos, D. C. (2014). Relação entre solos afetados por sais e concentração de metais pesados em quatro perímetros irrigados no Ceará. Revista Brasileira de Engenharia Agrícola e Ambiental, 18 (suppl.), 80-85. https://doi.org/10.1590/1807-1929/agriambi.v18nsupps80-s85

Das, S., Kim, G. W., Hwang, H. Y., Verma, P. P., \& Kim, J. P. (2019). Cropping with slag to address soil, environment, and food security. Frontiers in Microbiology, 10. https://doi.org/10.3389/fmicb.2019.01320

Deus, A. C. F. \& Büll, L. T. (2013). Eficiência de escórias de siderurgia na cultura do feijoeiro em sistema de semeadura direta. Ciência Rural, 43 (10), 17831789. https://doi.org/10.1590/S0103-84782013005000120.

Deus, A.C.F., Büll, L. T., Guppy, C. N., Santos, S. M. C., \& Moreira, L. L. Q. (2020). Effects of lime and steel slag application on soil fertility and soybean yield under a no till-system. Soil and Tillage Research, 196, 104422. https://doi.org/10.1016/j.still.2019.104422

Donagemma, G. K., Freitas, P. L., Balieiro, F. C., Fontana, A., Spera, S.T., Lumbreras, J. F., Viana, J. H. M., Araújo Filho, J. C., Santos, F. C., Albuquerque, M. R., Macedo, M. C. M., Teixeira, P. C., Amaral, A. J., Bortolon, E., \& Bortolon, L. (2016). Characterization, agricultural potential, and perspectives for the management of light soils in Brazil. Pesquisa Agropecuaria Brasileira, 51 (9), 1003-1020. https://doi.org/10.1590/s0100-204x2016000900001

Echart, C. L., \& Cavalli-Molina, S. (2001). Aluminum phytotoxicity: effevts, tolerance mechanisms and its genetic control. Ciência Rural, 31, 531-541. https://doi.org/10.1590/S0103-84782001000300030

Empresa Brasileira de Pesquisa Agropecuária [EMBRAPA] (2018). Brazilian Soil Classification System (5a ed). Brasilia: Embrapa.

Esper Neto, M., Coneglian, C. F., Costa, A. C. S., Inoue, T. T., \& Batista, M. A (2019). Short-term effects of liming on chemical attributes of tropical sandy soil and soybean (Glycine max L.) yield. Australian Journal of Crop Science, v. 13 (6), 889-894.

Fageria, N. K., \& Stone, L. F. (2008). Micronutrient deficiency problems in South America. In Alloway, B. Micronutrient Deficiencies in Global Crop Production (Chap. 10, pp. 245-266). Dordrecht: Springer. https://doi.org/10.1007/978-1-4020-6860-7_10

Fernandes, M. M., Carvalho, M. G. C., Araújo, M. R., Melo, F. R., Silva, C. A., Sampaio, F. M. T., \& Lobato, M. G. R. (2012). Matéria orgânica e biomassa microbiana em plantios de eucalipto no cerrado piauiense. Floresta e Ambiente, 19 (4), p. 453-459. https://doi.org/10.4322/floram.2012.061

Ferreira, A. O., Sá, J. C. M., Lal, R., Tivet, F., Briedis, C., Inagaki, T. M., Gonçalves, D. R. P., \& Romaniw, J. (2017). Macroaggregation and soil organic carbon restoration in a highly weathered Brazilian Oxisol after two decades under no-till. Science of the Total Environment, 621 (2017), 1559-1567. https://doi.org/10.1016/j.scitotenv.2017.10.072 
Fryrear, D. W. (1990). Wind erosion: mechanics, prediction, and control. In: Singh, R. P., Parr, J. F., \& Stewart, B. A. Advances in Soil Science (Vol. 13, pp. 187-199). New York: Springer-Verlag. https://doi.org/10.1007/978-1-4613-8982-8_9

Gil, A. C. (2018). Como elaborar projetos de pesquisa (6a ed). São Paulo: Atlas.

Ghosh, A., \& Ghosh, A. K. (2020). Solid Waste Management in Steel Industry-Challenges and Opportunities. In:Ghosh, S. K. (Ed.) Sustainable Waste Management: Policies and Case Studies (Vol. 1, pp. 299-307). Singapore: Springer Nature. https://doi.org/10.1007/978-981-13-7071-7_27

Gomes, H. I., Mayes, W. M., Rogerson, M., Stewart, D. I., \& Burke, I. T. (2016). Alkaline residues and the environment: a review of impacts, management practices and opportunities. Journal of Cleaner Production, 112 (4), 3571-3582. https://doi.org/10.1016/j.jclepro.2015.09.111

Gomes, L., Simões, S. J. C., Nora, E. L. D., Sousa-Neto, E. R., Forti, M. C., \& Ometto, J. P. H. B. (2019). Agricultural expansion in the Brazilian Cerrado: Increased soil and nutrient losses and decreased agricultural productivity. Land, 8 (1), 1-26. https://doi.org/10.3390/land8010012

Guo, J., Bao, Y., \& Wang, M. (2018). Steel slag in China: Treatment, recycling, and management. Waste management, 78, 318-330. https://doi.org/10.1016/j.wasman.2018.04.045

Gwon, H. S., Khan, M. I., Alam, M. A., Das, S., \& Kim, P. J. (2018). Environmental risk assessment of steel-making slags and the potential use of LD slag in mitigating methane emissions and the grain arsenic level in rice (Oryza sativa L.). Journal of hazardous materials, $353,236-243$. https://doi.org/10.1016/j.jhazmat.2018.04.023

Hunke, P., Mueller, E. N., Schröder, B., \& Zeilhofer, P. (2015). The Brazilian Cerrado: assessment of water and soil degradation in catchments under intensive agricultural use. Ecohydrology, 8 (6), 1154-1180. https://doi.org/10.1002/eco.1573

Instituto Aço Brasil [IAB] (2014). Relatório de Sustentabilidade 2014. Rio de Janeiro.

Instituto Aço Brasil [IAB] (2020). Folder Aço e Sustentabilidade 2020. https://acobrasil.org.br/site/wp-content/uploads/2019/08/SUSTENTAB_digital_20201.pdf

International Business Machines [IBM Corp.] (2019). IBM SPSS statistics for Windows, version 26.0. New York: IBM Corporation.

Jenny, H. (1980). The soil resource: origin and behavior (1a ed.). New York: Springer-Verlag.

Jiang, Y., Ling, T. C., Shi, C., \& Pan, S. Y. (2018). Characteristics of steel slags and their use in cement and concrete-A review. Resources, Conservation and Recycling, 136, 187-197. https://doi.org/10.1016/j.resconrec.2018.04.023

Kimio, I. T. O. (2015). Steelmaking Slag for Fertilizer Usage. Nippon Steel Sumitomo Metal Tech Rep, 109, 130-136.

Lal, R. \& Stewart, B. A. (2019). Soil and Climate. New York: CRC Press.

Li, Y., Cui, S., Chang, S. X., \& Zhang, Q. (2019) Liming effects on soil pH and crop yield depend on lime material type, application method and rate, and crop species: a global meta-analysis. Journal of Soils and Sediments, 19 (3), 1393-1406. https://doi.org/10.1007/s11368-018-2120-2

Liubartas, D., de Barros, E. A. S., dos Santos, E. A. M., da Silva, J. E., \& Formigoni, A. (2015). A sustentabilidade do aço e das estruturas metálicas. INOVAE - Journal of Engineering and Technology Innovation, 3 (1), 92-110.

Lopes, A. S. \& Cox, F. R. (1977). A survey of the fertility status of surface soils under "Cerrado" vegetation in Brazil. Soil Science Society of America Journal, 41 (4), 742-747. https://doi.org/10.2136/sssaj1977.03615995004100040026x

Lopes, A. S. \& Guilherme, L. R. (2016). A career perspective on soil management in the Cerrado region of Brazil. In Sparks, D. L. (Ed.) Advances in Agronomy (Vol. 137, Chap.1, pp. 1-72). London: Elsevier Inc. https://doi.org/10.1016/bs.agron.2015.12.004

Lozano-Lunar, A., Silva, P. R., Brito, J., Alvarez, J. I., Fernández, J. M., \& Jimenez, J. R. (2019). Performance and durability properties of self-compacting mortars with electric arc furnace dust as filler. Journal of Cleaner Production, 219, 818-832. https://doi.org/10.1016/j.jclepro.2019.02.145

Lumbreras, J. F., Carvalho Filho, A. D., Motta, P. E. F., Barros, A. H. C., Aglio, M. L. D., Dart, R. D. O., \& Freitas, P. L. (2015). Aptidão agrícola das terras do Matopiba.Embrapa Solos-Documentos (INFOTECA-E), 179, 49.

Marconi, M. A.; Lakatos, E. M. (2017). Fundamentos de metodologia científica. (8a ed). São Paulo: Atlas.

Meena, V., Dotaniya, M. L., Saha, J. K., Meena, B. P., Das, H., \& Patra, A. K. (2020). Sustainable C and N Management Under Metal-Contaminated Soils. In: Datta, R., Meena, R. S., Pathan, S. I., \& Ceccherini, M. T. (Eds.) Carbon and Nitrogen Cycling in Soil (pp. 293-336). Singapore: Springer Nature. https://doi.org/10.1007/978-981-13-7264-3_9

Ministério da Agricultura, Pecuária e Abastecimento [MAPA] (2017). Manual de métodos analíticos oficiais para fertilizantes e corretivos. Brasília: MAPA.

Nascimento, A. L., Junio, G. R. Z., Sampaio, R. A., Fernandes, L. A., Carneiro, J. P., \& Barbosa, C. F. (2015). Metais pesados no solo e mamoneira adubada com biossólido e silicato de cálcio e magnésio. Revista Brasileira de Engenharia Agrícola e Ambiental, 19 (5), 505-511. https://doi.org/10.1590/18071929/agriambi.v19n5p505-511

Nascimento, E. V. S., Brasil, E. C., \& Silva, G. R. (2019). Efeito da escória de siderurgia nos atributos químicos de um Lato ssolo amarelo distrófico em Terra Alta-PA. Revista Agroecossistemas, 11 (1), 97-121. http://dx.doi.org/10.18542/ragros.v11i1.2163

Ning, D., Liang, Y., Liu, Z., Xiao, J., \& Duan, A. (2016). Impacts of steel-slag-based silicate fertilizer on soil acidity and silicon availability and metalsimmobilization in a paddy soil. PLOS One, 11 (12). https://doi.org/10.1371/journal.pone.0168163 
Nogueira, N. O., Tomaz, M. A., Andrade, F. V., Reis, E. F. D., \& Brinate, S. V. B. (2012). Influência da aplicação de dois resíduos industriais nas propriedades químicas de dois solos cultivados com café arábica. Revista Ciência Agronômica, 43 (1), 11-21. https://doi.org/10.1590/S180666902012000100002

Nolla, A., Korndörfer, G. H., da Silva, T. R. B., \& Saraiva, A. (2013). Correção da acidez de um Neossolo submetido à aplicação de carbonato e silicato de cálcio. Journal of Agronomic Sciences, 2 (1), 113-120.

Nunes, Í. L., Afonso, R. L. C., Silva, B. A., Rocha, G. C., Minette, L. J., de Lima, N. N., \& Miranda, C. F. M. (2020). Spatial variability of soil physical properties as a result of different tillage systems. Brazilian Journal of Development, 6 (7), 42619-42631. https://doi.org/10.34117/bjdv6n7-034.

Oliveira, F. K. D., \& Souza, A. A. L. (2020). Potencial fitorremediador do "feijão-de-porco" submetido a diferentes concentrações de escória de siderurgia. Hollos, 2, 1-13. https://doi.org/10.15628/holos.2020.6609

Oza, E. F., Monaco, P. A. V. L., Santos, M. M. D., Rosado, T. L., Krause, M. R., \& Garcia, W. A. (2018). Aproveitamento de escória de siderurgia em substratos alternativos para produção de mudas de pimenteira Dedo-de-moça. Revista Ceres, 65 (1), 104-109. https://doi.org/10.1590/0034$737 \times 201865010014$

Özbay, E., Erdemir, M., \& Durmuş, H. I. (2016). Utilization and efficiency of ground granulated blast furnace slag on concrete properties - A review. Construction and Building Materials, 105, 423-434. https://doi.org/10.1016/j.conbuildmat.2015.12.153

Ozores-Hampton, M., Stansly, P. A., \& Salame, T. P. (2011). Soil chemical, physical, and biological properties of a sandy soil subjected to long-term organic amendments. Journal of Sustainable Agriculture, 35 (3), 243-259. https://doi.org/10.1080/10440046.2011.554289

Pereira, H. S., Gama, A. J. M., Camargo, M. S. D., \& Korndorfer, G. H. (2010). Reatividade de escórias silicatadas da indústria siderúrgica. Ciência e Agrotecnologia, 34 (2), 382-390. https://doi.org/10.1590/S1413-70542010000200016

Pereira, H. S., Korndörfer, G. H., Vidal, A. D. A., \& Camargo, M. S. D. (2004). Silicon sources for rice crop. Scientia agrícola, 61 (5), 522528.https://doi.org/10.1590/S0103-90162004000500010

Piatak, N. M., Parsons, M. B., \& Seal, R. R. (2015). Characteristics and environmental aspects of slag: A review. Applied Geochemistry, 57, 236-266. https://doi.org/10.1016/j.apgeochem.2014.04.009

Pullin, H., Bray, A. W., Burke, I. T., Muir, D. D., Sapsford, D. J., Mayes, W. M., \& Renforth, P. (2019). Atmospheric carbon capture performance of legacy Iron and steel waste. Environ Sci Techno, 53 (16), 9502-9511. https://doi.org/10.1021/acs.est.9b01265.

Ranger, J. (2018). Forest Soils: Characteristics and Sustainability. InBerthelin, J., Valentin, C., \& Munch, J. C (Eds.) Soils as a Key Component of the Critical Zone 1: Functions and Services (Vol. 1, Chap. 7, pp. 163-186). London: ISTE Ltd. https://doi.org/10.1002/9781119438069.ch7

Reichardt, K., \& Timm, L. C. (2016). Água e sustentabilidade o Sistema solo-planta-atmosfera. Barueri: Manole.

Reichert, J. M., Amado, T. J. C., Reinert, D. J., Rodrigues, M. F., \& Suzuki, L. E. A. S. (2016). Land use effects on subtropical, sandy soil under sandyzation/ desertification processes. Agriculture, Ecosystems and Environment, 233, 370-380. https://doi.org/10.1016/j.agee.2016.09.039

Rocha, M. C., Binow, T. D., Raimam, M. P., \& Albuquerque, A. R. (2019, Maio). Lixiviação sobre solos tratados com coproduto siderúrgico associado ao comportamento de $\mathrm{pH}$. Anais do Simpósio de gestão do conhecimento e biodiversidade da Flona Tapirapé-Aquiri, Marabá, PA, Brasil. https://pt.scribd.com/document/431322216.

Rodrigues, L. U., \& Silva, R. R. (2020). Boron availability in building up fertility in Cerrado Soil of Tocantins. Communications in soil science and plant analysis, 51, (5), 595-603. //doi.org/10.1080/00103624.2020.172937.

Sadek, D. M. (2014). Effect of cooling technique of blast furnace slag on the thermal behavior of solid cement bricks. Journal of Cleaner Production, 79, 134141. https://doi.org/10.1016/j.jclepro.2014.05.033

Santos, N. G. N., Olszevski, N., Salviano, A. M., Cunha, T. J. F., Giongo, V., \& Pereira, J. S. (2019). Granulometric fractions and physical-hydric behavior of sandy soils. Revista Agrarian, Dourados, 12 (45), 318-327. https://doi.org/10.30612/agrarian.v12i45.7687

Scattolin, M., Peuble, S., Pereira, F., Paran, F., Moutte, J., Menad, N., \& Faure, O. (2021). Aided-phytostabilization of steel slag dumps: The key-role of pH adjustment in decreasing chromium toxicity and improving manganese, phosphorus and zinc phytoavailability. Journal of Hazardous Materials, 405 (5), 124225. https://doi.org/10.1016/j.jhazmat.2020.124225.

Schaetzl, R. J., \& Thompson, M. L. (2015) Soils: Geomorphology and Genesis (2a ed). New York: Cambridge University Press.

Seh-Bardan, B. J., Sadegh-Zadeh, F., Seh-Bardan, E. J., \& Wahid, S. A. (2013). Effects of Electric-Arc Furnace Dust Application on Soil Properties, Sorghum Growth, and Heavy-Metal Accumulation. Communications in Soil Science and Plant Analysis, 44, (11), 1674-1683. https://doi.org/10.1080/00103624.2013.783057

Serafim, M. E., Zeviani, W. M., Ono, F. B., Neves, L. G., Silva, B. M., \& Lal, R. (2019). Reference values and soil quality in areas of high soybean yield in Cerrado region, Brazil. Soil and Tillage Research, 195, 104362. https://doi.org/10.1016/j.still.2019.104362

Siderúrgica Norte Brasil [SINOBRAS] (2019). Relatório dos resíduos siderúrgicos ano de 2019. Marabá: SINOBRAS.

Siderúrgica Norte Brasil Florestal [SINOBRAS FLORESTAL] (2019). Relatório de fertilidade do solo: Fazenda são bento do Tocantins - TO. Marabá: SINOBRAS.

Silva, M. O., Veloso, C. L., Nascimento, D. L., Oliveira, J., Pereira, D. F., \& Costa, K. D. S. (2020). Indicadores químicos e físicos de qualidade do solo. Brazilian Journal of Development, v. 6, n. 7, p. 47838-47855. https://doi.org/10.34117/bjdv6n7-431 
Silva, P. L. F., Oliveira, F. P., Borba, J. D. M., Tavares, D. D., Amaral, A. J., \& Martins, A. F. (2018). Solos arenosos para sistemas de integração lavourapecuária-floresta em Arez, Rio Grande do Norte. Revista Verde de Agroecologia e Desenvolvimento Sustentável, 13 (5), 581.

Sobral, M. F., do Nascimento, C. W., da Cunha, K. P., Ferreira, H. A., Silva, A. J., \& Silva, F. B. (2011). Basic slag and its effects on the concentration of nutrients and heavy metals in sugarcane. Revista Brasileira de Engenharia Agrícola e Ambiental, 15 (8), 867-872. https://doi.org/10.1590/S141543662011000800015

Sol-Sánchez, M., Castro, J., Ureña, C., \& Azañón, J. M. (2016). Stabilisation of clayey and marly soils using industrial wastes: pH and laser granulometry indicators. Engineering Geology, 200, 10-17. https://doi.org/10.1016/j.enggeo.2015.11.008

Stathopoulos, V. N., Papandreou, A., Kanellopoulou, D., \& Stournaras, C. J. (2013). Structural ceramics containing electric arc furnace dust. Journal of Hazardous Materials, 262, 91-99. https://doi.org/10.1016/j.jhazmat.2013.08.028

Sumner, M. E., \& Noble, A. D. Soil acidification: The world story. In Rengel, Z. (Ed.) Handbook of Soil Acidity (pp.1-28). New York: Marcel Dekker.

Teixeira, C. P., Donagemma, G. K., Fontana, A., \& Teixeira, W. G. (2017). Manual de Métodos de análise de solo (3a ed.). Brasília: Embrapa.

Teo, P. T., Zakaria, S. K., Salleh, S. Z., Taib, M. A. A., Sharif, N. M., Seman, A. A., Mohamed, J. J., Yusoff, M., Yusoff, A. H., Mohamad, M., Masri, M. N., \& Mamat, S. Assessment of Electric Arc Furnace (EAF) Steel Slag Waste's Recycling Options into Value Added Green Products: A Review. Metals, 10 (10), 1347.https://doi.org/10.3390/met10101347.

Verruijt, A. (2018). An Introduction to Soil Mechanics. Cham: Springer.

Wally, M. S., Bissani, C. A., Santos, V. P., Bortolon, L., Bortolon, E. S. O., \& Gianello, C. (2015). Correção da acidez do solo e aporte de metais pesados pela aplicação de escória básica de aciaria. Bioscience Journal, Uberlândia, 31 (1), 135-145. https://doi.org/10.14393/BJ-v31n1a2015-22236

Wan, M., Hu, W., Qu, M., Tian, K., Zhang, H., Wang, Y., \& Huang, B. (2019). Application of arc emission spectrometry and portable X-ray fluorescence spectrometry to rapid risk assessment of heavy metals in agricultural soils. Ecological Indicators, 101, 583-594. https://doi.org/10.1016/j.ecolind.2019.01.069

Wang, Y., Ge, L., Chendi, S., Wang, H., Han, J., Guo, Z., \& Lu, Y. (2020). Analysis on hydraulic characteristics of improved sandy soil with soft rock. PLoS ONE, 15 (1), 1-13. https://doi.org/10.1371/journal.pone.0227957

Xu, D., Carswell, A., Zhu, Q., Zhang, F., \& Vries, W. (2020). Modelling long-term impacts of fertilization and liming on soil acidification at Rothamsted experimental station. Science of the Total Environment, 713, 136249. https://doi.org/10.1016/j.scitotenv.2019.136249

Yong, R. N., Nakano, M., \& Pusch, R. (2012). Environmental soil properties and behaviour. Boca Raton: CRC Press. 